\title{
視線追従型映像提示系への応用を目的とした 注視点近傍における視賞特性の検討”
}

\section{岩本和世**, 前田太郎 ${ }^{* * *}$, 谷江和雄 ${ }^{* *}$}

Currentry, there are several types of Head Mounted Display (HMD) commercially available for virtual reality systems. The HMD uses two LCD displays to present the different image to each eye and enables a user to see stereo images. In order to display realistic images, the HMD is required to have the enough size screen which covers the whole visual field. In almost HMDs, however, the size of screen is not enough large because the use of the wider one will make the image resolution lower. As long as the NTSC display is introduced, there is a difficulty of overcoming this problem because of the restriction of the scanning lines. One of solutions for this is to introduce the Eye Movement Tracking Type HMD (EMT-HMD). Human eye can see the object precisely only at the area near to view point. With this in mind, the idea of EMT-HMD has been proposed which presents higher resolution images at the area near view point rather than the peripheral area. This paper describes the characteristics of human central vision useful to design such an image display system for EMT-HMD. In experiments, several grating fmages with higher spatial frequencies at view point area were used. The images which have the various frequencies at the central and peripheral area, were presented to several subjects. Each subject was asked if he/she could recognize the difference of the resolution and required to answer the size of the high spatial frequency area at which the difference can not be recognized. From these experiments, the size of high resolution area was determined as a function of the difference of resolution. Based on these results, how to design the size of the high resolution area in EMT-HMD using NTSC display devices was provided.

仮想現実感技術における視覚情報の提示装置としてヘッドマウントディスプレイ (HMD) が注目さ れている.HMD の基本原理は両眼前方に個別のディスプレイを用意し，それに視差のある映像を映し てステレオ感のある像を提示するものである. 臨場感の高い映像提示機能をもつHMD を得るには, 人の視野全体に，十分な解像度の映像を提示するディスプレイ系を構築することが望まれる. 現状の HMD の多くはNTSC 方式のディスプレイを用いているが, 走査線数が 525 本の NTSC ディスプレ イでは, 人の視野を覆うに十分な大きさのものを用いると走査線間隔が広がり, 明瞭な映像提示が困 難になる．そこで, 解像度を損なわない程度の大きさのディスプレイを導入する結果，人の視野を覆 うに十分な大きさの映像が提示できず，臨場感の点で問題を残しているのが実情である．この問題を 解決するひとつの方法として，視線追従型 HMD（EMT-HMD）を導入することが検討されている. 一般に人の眼は, 注視点近傍において対象を高い分解能で観測することができる.EMT-HMD は注視

$*$ 平成 5 年 4 月 19 日受付

** 工業技術院 機械技術研究所

Mechanical Engineering Lab., AIST-MITI.
*** 東京大学 先端科学技術研究センター

Research Center for Advanced Sci. and Tech., Univ. of Tokyo. 
点周囲の限られた領域のみに高解像の映像を提示し，その周囲には低解像だが視野の広い像を提示す ることによって, NTSC 方式の走查線数のディスプレイを用いて, 等価的に広視野・高解像の映像を 提示するシステムである. 本論文では, こうした EMT-HMD のための画像提示系を設計するのに有 用な人の中心視特性を実験的に検討している，実験においては，視野の特性を調べるための標準パ夕 ーンとして白黒の縞模様パターンを用いた。この縞模様に空間平均処理を施して, 注視点近傍に高い 分解能, 周囲に低い分解能をもつ種々の縞模様の画像を作成し, それを被験者に提示して中心・周囲 の境界が区別できなくなる注視点近傍の領域の大きさを判定させた，この結果より，各種の異なる中 心・周囲の分解能の組み合わせと, 境界が検知できなくなる注視点近傍領域の大きさとの関係を明ら かにした. またこの関係をもとに, NTSC 方式のディスプレイを用いて EMT-HMD を構成する際に おける, 注視点近傍の高解像映像ディスプレイ領域の設計法を示した.

(キーワード : ヘッドマウントディスプレイ, HMD, 視線追従型 HMD, 高解像度視野角, 分解能, 中心視, 周辺視)

\section{1. まえがき}

近年, 人工現実感技術が新しいヒューマンインタフ エース技術として注目を集めている。この技術では高 い臨場感をもって仮想環境あるいは実環境をオペレー 夕に提示することが求められており，これを実現する 装置のひとつとしてヘッドマウントディスプレイ（以 下, HMD と略)が注目されている ${ }^{1)}$. 高い臨場感をも って視覚情報を提示する方法としては, ステレオ写真 に代表されるように左右両眼に別々の二次元映像を提 示し，これを両眼視させることで奥行き感のある像を 提示する方法が知られている. HMD でも類似の方法 を用いたいわゆるステレオ型提示装置が開発されてい る。たとえば装着者の両眼に液晶ディスプレイ (LCD) などを用いて二次元映像を提示し，仮想的に装着者の 周囲に三次元の視空間を構成する装置が市販されてい る.そのひとつの構成例を図 1 に示す ${ }^{11}$.

このシステムは上部に左右両眼に対応する $2 つ 0$ LCD を有し, ユーザは LCD に映し出される映像を眼

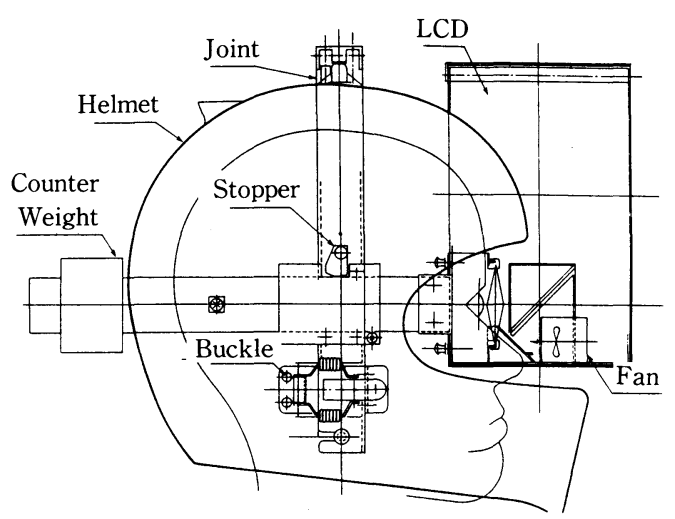

図 1 HMD の一構成例

Fig. 1 An example of HMD.
前に配置されたミラーを介して観測することで，ステ レオ像を見ることができる。

ところで，こうした HMD では，ディスプレイが人 の最大視野よりも小さいとディスプレイの枠が視界に 入り, 臨場感が損なわれる. 視野を十分カバーできる ディスプレイを導入することが臨場感を確保するうえ では必要であるが，一方において通常のディスプレイ （NTSC 方式）は走査線の数（525 本）が限られるた め, 大画面にすると提示映像の分解能が落ち, 臨場感 の高い像が必ずしも提示できない。そこで既開発の HMD では必要な分解能を確保できる大きさのディス プレイを用いているのが実状であり，人の視野を覆う 映像を提示する意味では必ずしも仕様的に十分なもの ではない.

この問題を解決する最も直接的方法は, より高解像 な走査線を有するディスプレイを開発することにある ことはいうまでもない.しかし筆者らの試算では, 八 イビジョンの走査線数 (約 2000 本) でも, 人の視野を 覆うに十分な大きさのディスプレイを用いると，人の 視力換算で 0.1 程度の分解能の映像しか提示できない (付録参照). 八イビジョンを超えるディスプレイデバ イスの開発にはかなり時間を要することを前提とすれ

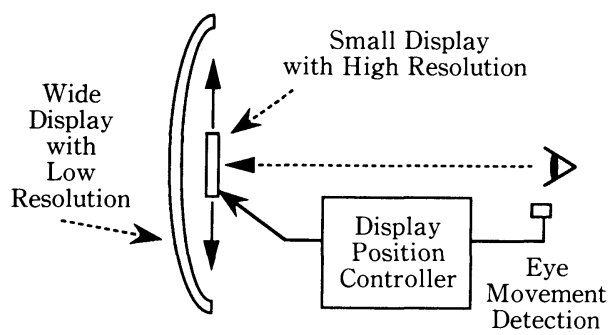

図 2 視線追従型 HMD の概念図

Fig. 2 The concept of eye movement tracking type head mounted display (EMTHMD). 
ば，別の広視野・高解像度映像提示方式が検討される 必要がある。

こうした試みのひとつとして，人の視覚系がもつ生 理学的特性を利用した視線追従方式の映像提示法が提 案されている21. 図 2 にその概念図 ${ }^{3)}$ を示す。すなわ ち, 人間の視覚が視線の中心周辺でのみ高分解能の像 を受容する能力をもつ4)ことに注目し, 眼球の動きを 検知して, それから求めた視線方向の一定領域に高解 像度の像を提示し, その周囲には, 解像度は低いが広 画面の映像を提示する映像提示法である.この方法は 広視野・高解像度映像提示の課題を, いわばオプトメ カトロニクス的方法で解決しようとするもので, 近い 将来に目的のシステムを得るための有力な方法と考え られる。

ところで, この種の視線追従型 HMD の開発では, 視線に追従させて提示する高解像度映像を, 背景の広 画面ディスプレイ映像に重ね合わせていることを意識 させないようにすることが重要である. 高解像度化を 意識した視線追従型 HMD の設計の試みとしては, Dalton らが視野角 36 度 (対角) の高解像度提示系をも つHMD の設計を行っているが5), 背景に与えるべき 像の解像度と高解像度提示系の視野角についての一般 的な検討は行っていない.一方, HMD 設計に有用と思 われる視覚特性としては, 人の視覚系の基礎研究分野 において, 網膜の中心窩周囲および周辺視の視力特性 が定量的に調べられている ${ }^{6)}$. また眼球の運動特性に ついても多くの研究成果があり, 追従運動と断続運動 の 2 種の眼球運動形態の存在や, 特に後者では視力が 低下するなど運動中の視力特性も一部明らかにされて

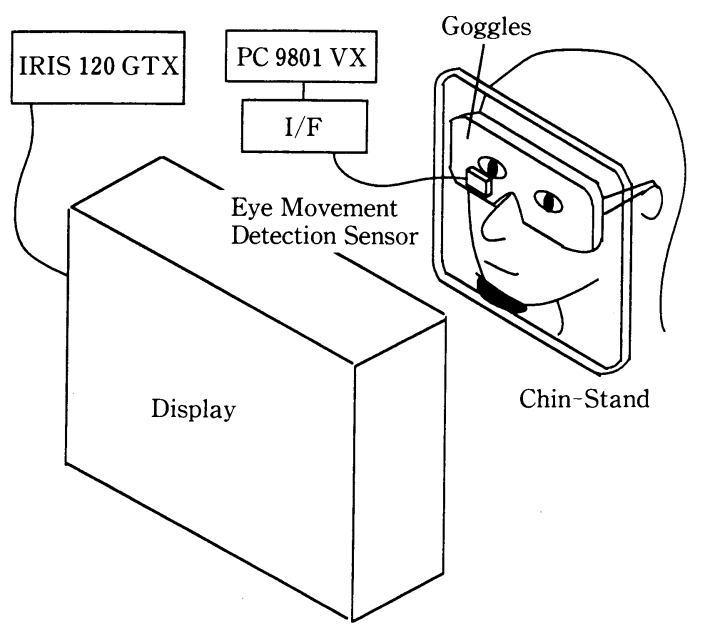

図 3 実験装置

Fig. 3 Experimental setup.
いる7).

また HMDへの応用を意識した研究としては，山口 らが, SMPTE標準像を用いた心理物理実験により, 視線中央の視野角 20 度より外側の領域では空間周波 数 3 cpd (cycle per degree) 以下の分解能の映像の差 は知覚できないことを明らかにしている2．また， Virsu らは白黒格子模様を用いて, 視野角と識別でき る空間周波数の関係を調べている ${ }^{8)}$. これら過去の研 究のデータは高解像度ディスプレイの視野角决定に一 部手がかりを与えるものといえる。しかし，システム の最適設計を目指すうえでは十分とはいえない. 分解 能の異なる重畳された 2 つ映像の境界の識別のしゃ すさは, 高解像度映像の大きさに依存することはもち ろんであるが，それだけでなく背景となる広画面低解 像度の映像との分解能の差にも依存する. すなわち, 上記のディスプレイ設計の基礎データとしては, 背景 画像の分解能をパラメータとした高解像ディスプレイ 視野角の検討が不可欠である.

本論文では視線追従型高解像度 HMD 設計の基礎 データを得ることを目的として，人の中心視野および 周辺視野の視力特性を心理物理的手法により検討した 結果と,それに基づき NTSCディスプレイで視線追従 型 HMD を構成した場合の高解像度視野角の大きさ について考察した結果を報告する。

\section{2. 実験装置}

実験装置は図 3 に示すように映像提示装置と視線検 出装置および顎台から構成され, 被験者はディスプレ イ前面にある顎台に顔を固定し, 視線検出センサを取 りつけた状態でディスプレイの提示模様を注視する. 映像提示装置としては, IRIS 120 GTX (シリコング ラフィックス社製）を使用した.ディスプレイの大き さは 19 インチで, 横 1280 画素, 縦 1024 画素の分解能 のコンピュータ生成映像表示が可能である.これによ

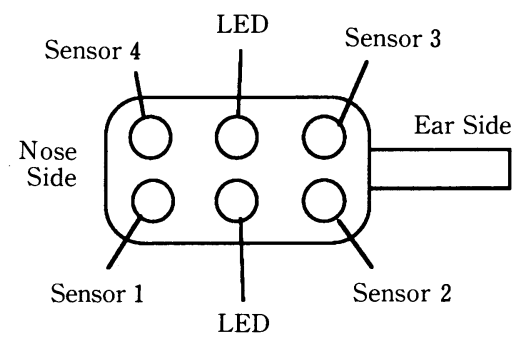

図 4 視線検出センサ

Fig. 4 Eye movement detection sensor. 
り, 画面より $20 \mathrm{~cm}$ 離れた位置から提示映像を観測す るとすれば，像の分解能 (詳細は後述) は最大 $6.5 \mathrm{cpd}$ で, 水平方向約 88 度, 垂直方向約 71 度の視野角を確 保できる.ディスプレイはカラー表示が可能であるが, 実験では白黒映像を用いた。その輝度は白から黒まで 256 段階の調整が可能である.

視線検出装置としては, 赤外 LED と 4 つのフォト ダイオードから構成される市販の眼球検出センサ（竹 井機器製）を用いた．外観図を図 4 に示す，中央の赤 外 LED からの光を眼球に当て，その反射光をフォト ダイオードで受光する構造であり, 白眼と黒眼の反射 特性の違いを利用して眼球位置を検出するものである. 各ダイオードの出力は約 $60 \mathrm{~ms}$ のサンプリングタイ ムで $\mathrm{AD}$ 変換器を介してコンピュータ (PC $98 \mathrm{VX})$ に 読み込み，視線検出処理を行うとともに，その動きを メモリに記憶した。この視線検出装置は眼鏡の右眼つ レームに取りつけられ，実験中の被験者の視線位置を モニタするために用いられた。

顎台は，被験者がその上に顎をのせたときに眼球位 置がほぼブィスプレイ前方 $20 \mathrm{~cm}$ または $60 \mathrm{~cm}$ にく るように設置した。被験者は視線検出セン少付の眼鏡 をかけて顎を固定し，ディスプレイに表示される各種 映像の識別実験を行った.

\section{3. 実験方法}

図 2 の視線追従型提示系において, 高解像度映像提 示領域の大きさを決定する基礎デー夕を得るために， 視線近傍領域に抢いて高解像, その周辺領域で低解像 の映像を提示し, 高解像の領域をどの程度にすれば,

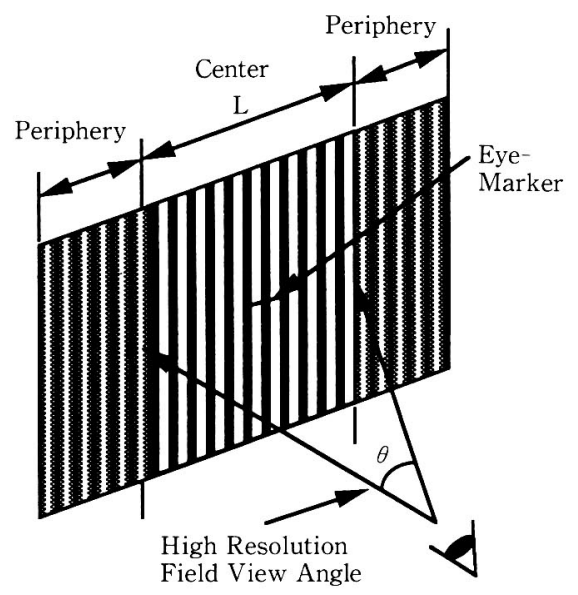

図 5 変化刺激の構造

Fig. 5 The structure of variable stimulus.
その境界の存在が検知できなくなるかを評価する実験 を行う. 人がカバーする視野は二次元的ひろがりをも つ.したがって人の視覚特性を考える場合, 水平・垂 直両方向の特性を考慮すべきであるが，垂直方向の眼 球の運動領域は水平方向のそれに比べて狭いことか $ら^{99}$, 本研究では特に水平方向の特性のみ検討する.

実験では白黒の格子縞パターンを標準パターンに採 用し, 極限法 ${ }^{10)}$ を用いて以下の手順で行った。まず基 準刺激として全面同じ分解能の縦縞模様, 変化刺激と して周辺が低解像度で中心部が基準刺激と同じ分解能 の綐縞模様を用い，基準刺激と変化刺激との対を提示 して両者の差を識別させた. 図 5 に変化刺激の構造を 示す。ここで，中心部の高解像度の縦縞模様の幅を L, それをカバーする視野角を高解像度視野角と定義し $\theta$ で表す。実験は, 上昇系列, 下降系列の 2 種の実験か ら構成される。上昇系列実験では, 確実に基準刺激と の差が識別できるある変化刺激がもつ中心部高解像領 域の幅を $\mathrm{L}_{1}$ とするとき， $\mathrm{L}_{1}<\mathrm{L}_{2}<\mathrm{L}_{3} \cdots$ なる刺激を 用意し，この順にそれぞれ基準刺激との比較を行わせ た。また下降系列実験では, まず基準刺激と識別でき ない中心部の幅 $\mathrm{L}_{\mathrm{n}}$ をつある変化刺激を選び，これ に対しさらに $\mathrm{L}_{n}>\mathrm{L}_{n-1}<\mathrm{L}_{n-2} \cdots な る$ 刺激を選び，この 順に基準刺激との識別を行わせた。

回答は次の 3 種を選択させた。

（1）中心部高解像領域と周辺部低解像領域の境界が 明瞭に識別できる。

（2）基準刺激と変化刺激の差はわかるが, 高解像領 域と低解像領域の境界は知覚できない。

（3）基準刺激と変化刺激の差がわからない.

各基準刺激-変化刺激対の識別では, 図 6 に示すよう に全画面黒, 基準刺激, 全画面黒, 変化刺激の順に各 1 秒ずつ提示した。 また被験者に高解像領域の中央を 注視させるために,これら 4 種の画像には中央にEyeMarker (図 5 ) を併せて表示し，それを注視しつつ識 別を行うことを要求した。 Eye-Marker を注視してい るか否かは，実験中，被験者に装着させた眼鏡に取り つけられている視線検出センサで確認した。識別中視 線が Eye-Marker からずれたことが確認された場合 は，そのデータは結果から削除した。

さて, 上記実験において中央部高解像領域と周囲低 解像領域の境界の識別のしやすさは, まえがきにも述 べたように高解像領域の大きさだけでなく, 両領域の 解像度の差にも依存寸る。 そこで上記実験は解像度を パラメータとして行った. 各種解像度の縦縞模様は次 に示すように, 画面上の各画素の輝度を空間平均処理 して作成した ${ }^{11}$. 本実験では前節で述べたように, 眼 球ーディスプレイ間距離を $20 \mathrm{~cm}$ または $60 \mathrm{~cm}$ として 


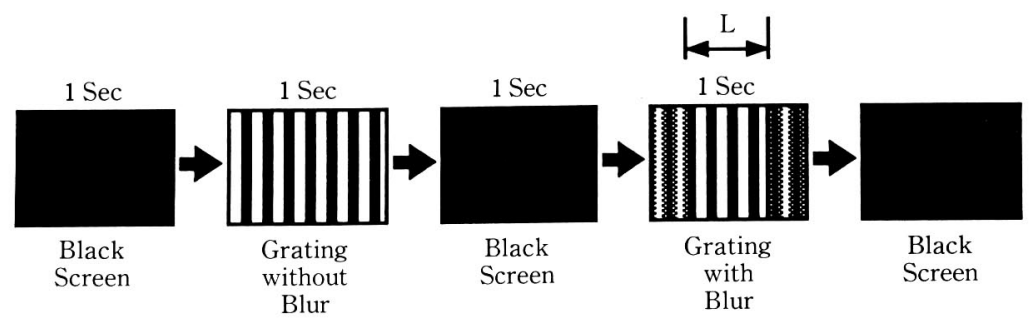

図 6 刺激パターンの提示手順

Fig. 6 The procedure of presenting stimuli.

いる. 距離 $20 \mathrm{~cm}$ の場合には, 視野角 1 度に対応する ディスプレイ上の幅は約 $3.5 \mathrm{~mm}$ である。この幅は使 用したディスプレイの水平方向分解能から換算すると 13 画素を含む。平均処理を加えない状態では 1 画素ご とに白と黒を表示できるので，このときの白と黒のサ イクルは 6.5 回/度となり, 分解能 $6.5 \mathrm{cpd}$ の縦縞が得 られる。これを使用した実験システムが発生できる最 高分解能縦縞模様とした。一方, 隣接する両画素を含 む3つの画素の輝度を平均化し，それを中央の画素の 位置の輝度とすれば, 白と黒のサイクルは 2.17 回/度 となるので, 分解能 $2.17 \mathrm{cpd} の$ 縦縞が得られる。これ を 2 番目に分解能の高い縦縞模様とした。 以下，同様 にして隣接する両側の 2 画素, 3 画素, 4 画素, 5 画 素の輝度を平均化して,それぞれ分解能 $1.30 \mathrm{cpd}$, $0.94 \mathrm{cpd}, 0.73 \mathrm{cpd}, 0.59 \mathrm{cpd} の$ 縦縞模様を作成した.

図 7 に, 以上に説明した分解能の異なる縞模様の作 成法を具体的に示す。たとえば各画素が白のとき輝度 100, 黒のとき輝度 0 で示すものとし, 図 7 a に隣接す る 1 画素の輝度を平均化することによって得られる $2.17 \mathrm{cpd}$ の輝度パターンを示す。同様に隣接する 2 画 素の輝度を平均化することによって得られる 1.30 $\operatorname{cpd}$ の輝度パターンを図 $7 \mathrm{~b}$ に示す. 以上に述べたも のより,さらに高い分解能の縦縞は, 眼球-ディスプレ イ間距離を $60 \mathrm{~cm}$ に離して同様の処理を行うことで 作成した。すなおち，このときの視野角 1 度に対応す るディスプレイ上の幅は約 $10.5 \mathrm{~mm}$ となる.したがっ てディスプレイの水平方向分解能から,この幅は 40 画 素を含む。 よって最高の分解能として $19.84 \mathrm{cpd}$ を得 る.一方, 隣接する両側の 2 画素, 4 画素, 7 画素の 輝度を平均化して，それぞれ $6.61 \mathrm{cpd}, 2.20 \mathrm{cpd}, 1.32$ cpdの縞模様を得た。

こうして作成したそれぞれの分解能の縦縞を, 中心 部高解像領域, 周辺部低解像領域に表 1 のように組み 合わせて変化刺激を作成し，それぞれについて上述の 比較実験を行った。ここで表 1 の条件 No. 1〜9 は, 眼 球一ディスプレイ間距離 $20 \mathrm{~cm}$, 条件 No. 10, 11 は距
離 $60 \mathrm{~cm}$ である. 条件 No. 4 と 11 では分解能条件は ほぼ等しいものを用いている.これは眼球-ディスプレ イ間距離 $20 \mathrm{~cm}$ と $60 \mathrm{~cm}$ の条件の違いが判定結果に 及ぼす影響を考察するために用意された。

一方，提示する縦縞模様は画素単位で白黒を反転し て表示するのが最も濃淡の細かいパターンとなるが, この場合, 平均処理により濃淡がすぐに均一化し, 上 述した処理による分解能の低いパターンの表示が困難 になるため, 視野角 1 度を 1 単位として白黒を反転さ せる縦縞模様を用いた。また表示パターンの輝度は, 最大能力を評価する立場から, 被験者が不快感をもた ない範囲の最大值を試行錯俁的に設定した。その值は 約 40 nit である.

実験を行うにあたっては，まず被験者に眼球運動検 出装置を取りつけた眼鏡をかけさせた，そしてディス プレイの前に置かれた顎台に顎を固定して座らせ，片 方の眼 (右眼) で図 6 の一組のパターンが提示されて

表 1 中心部および周辺部の分解能条件

Tab. 1 The resolution conditions in central area and periphery area.

\begin{tabular}{c|c|c}
\hline No. & 中心部の分解能 $(\mathrm{cpd})$ & 周辺部の分解能 $(\mathrm{cpd})$ \\
\hline 1 & 6.50 & 0.59 \\
\hline 2 & 6.50 & 0.73 \\
\hline 3 & 6.50 & 0.93 \\
\hline 4 & 6.50 & 1.30 \\
\hline 5 & 2.17 & 0.59 \\
\hline 6 & 2.17 & 0.73 \\
\hline 7 & 2.17 & 0.93 \\
\hline 8 & 1.30 & 0.59 \\
\hline 9 & 1.30 & 0.73 \\
\hline 10 & 19.84 & 2.20 \\
\hline 11 & 6.61 & 1.32 \\
\hline
\end{tabular}


いる間（4 秒）は瞬きをせずディスプレイを直視する よう要求した。このとき反対側の眼 (左眼) は眼帯で 遮へいした。

実験プロセスはすべてコンピュータのソフトで管理 されている，すなわち，実験開始の合図とともにコン ピュータはディスプレイ上に図 6 の手順でパターンを 発生し, 被験者の回答を待つ. 被験者が 3 種の回答の いずれかをキーボードに入力すると, 次のパターンが 提示される.上昇・下降系列実験のいずれにおいても， 各試行における最初の変化刺激は条件を満たすものの なかからランダムに選択し, 以下, 中心部高解像領域 の幅を高解像度視野角換算で眼球-ディスプレイ間距 離 $20 \mathrm{~cm}$ のとき 5 度ずつ, 距離 $60 \mathrm{~cm}$ のとき 2.5 度ず つ変化させた。

各系列の実験はそれぞれ 3 回行い, それらの平均值 を最終データとした。1系列の実験に要する時間は約 5 分である. 1 系列の実験 3 回はすべて連続して行っ たが，次の系列の実験に移る場合は，その間に十分な 休㮩時間をおいた。被験者は本実験の意味を周知して いる健常男子 3 名（ランドルト視力：0.3，1.2, 0.8 ), 女子 1 名 (同視力 : 1.0) である. ただし, 女子 被験者はコンタクトレンズ装着時の視力である。また, 視力 0.3 の被験者については, 眼球一ディスプレイ間距 離 $20 \mathrm{~cm}, 60 \mathrm{~cm}$ のうち, $60 \mathrm{~cm}$ のときには刺激提示パ ターンの識別能力が低下するため, 眼鏡を使用した矯 正視力下 (視力 1.0) で実験を行った. 実験はすべて暗 室で行われた．以上の実験手順の概要を図 8 に示す.

\section{4. 実験結果と考察}

図 $9 \mathrm{a}, \mathrm{b}$ に下降系列および上昇系列の実験結果の

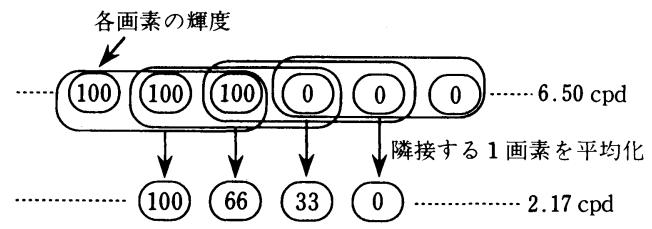

(a) 輝度分布パターン $(2.17 \mathrm{cpd})$

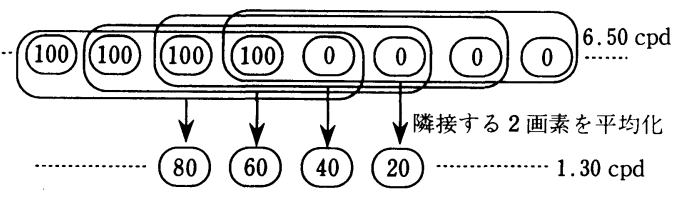

(b) 輝度分布パターン $(1.30 \mathrm{cpd})$

図 7 異なる分解能をもつパターンの作成法

Fig. 7 Method of generating patterns with different resolution.

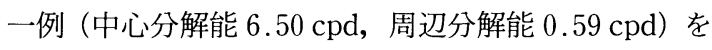
示す. 高解像度視野角 $\theta$ を横軸, 3 回の試行で得たそ れに対応する回答の平均值を縦軸に表示した。平均值 は前節で述べた回答(1)，(2)，(3)にそれぞれ得点 $1 ， 2$ ， 3 を与えて計算した。この図より, 上昇系列, 下降系 列とも境界を明瞭に識別できる場合(1)，あるいはでき ない場合(3)から曖昧な状態(2)を経て, 他の識別状態へ 移行していく傾向が認められる. 他の条件下での実験 についても同様の傾向を示す結果が得られた。

一方, 図 9 のデー夕を得た 3 回の実験のうちの 1 つ で測定された眼球運動検出センサの出力の時間経過を 図 10 に示す.それぞれのプロットは検出センサ中の 4 つのフォトダイオードの出力を示している.この結果 から, 実験中, 眼球位置はほぼ一定位置にあり, 変動 しないことがわかる.このフォトダイオードの出力は, ほぼ提示画面上に与えた Eye-Marker 位置を眼球が 注視しているときのそれに等しいことを，予備実験よ

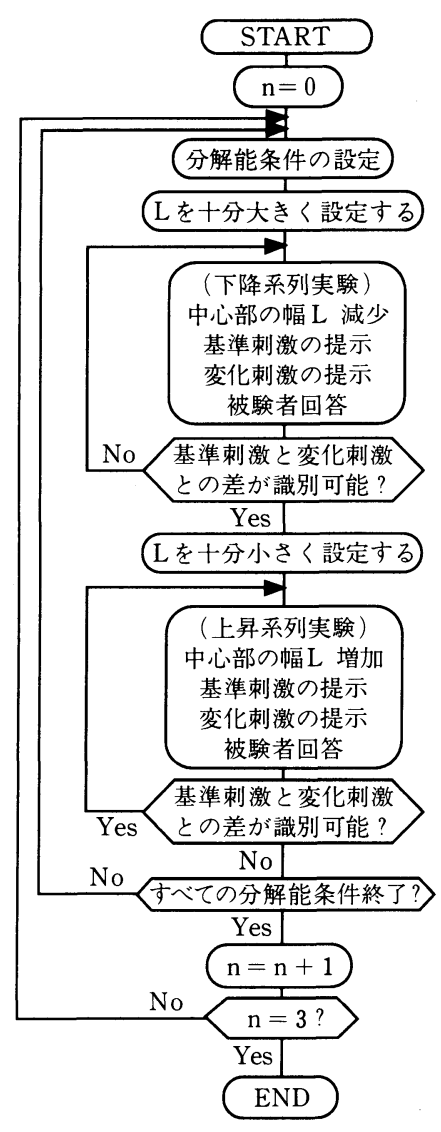

図 8 実験手順

Fig. 8 The flow chart of experimental procedure. 


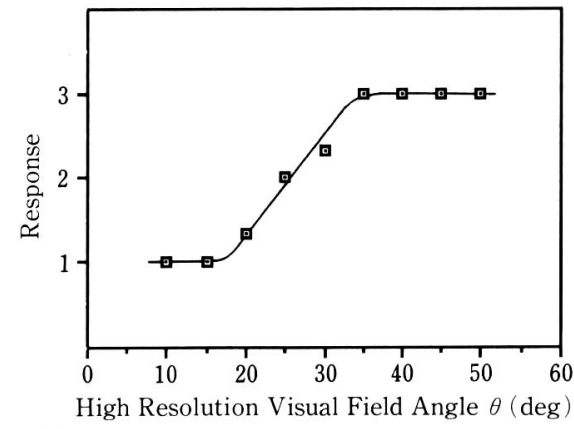

図 9 a 実験結果の例 (下降系列)

Fig. 9 a An example of experimental results (descending series).

り確認している。また他の実験に扔いても, 眼球が安 定に Eye-Marker を注視しつつ行われていることは， フォトダイオード出力より同様に確認できた。

表 1 に示した 11 種の中心部分解能, 周辺部分解能の 組それぞれに対して得た，上昇系列，下降系列実験デ ー夕の 3 回平均值より, 中心・周辺領域の境界が識別 できなくなるときの高解像度視野角 $\theta_{\mathrm{m}}$ は以下によっ て算出した。まず図 9 のような傾向をもつデータを 3 本の直線，すなわち回答が(1)〜 (3)あるいは(3)〜(1)に移 る傾斜部分を近似する直線，および回答(1)，(3)をそれ ぞれ通り横軸に平行な直線で近似する。次に，上昇系 列結果においては回答(1)を通る横軸に平行な直線と傾 斜部分の直線との交点に対応する高解像度視野角 $\theta_{\mathrm{u}}$, 下降系列では回答(3)を通る横軸に平行な直線と傾斜部 分の直線との交点に対応する高解像度視野角 $\theta_{\mathrm{d}}$ を求 め,これらの中間值を $\theta_{\mathrm{m}}$ とする.すなわち,

$$
\theta_{\mathrm{m}}=\left(\theta_{\mathrm{u}}+\theta_{\mathrm{d}}\right) / 2
$$

により $\theta_{\mathrm{m}}$ を算出する.

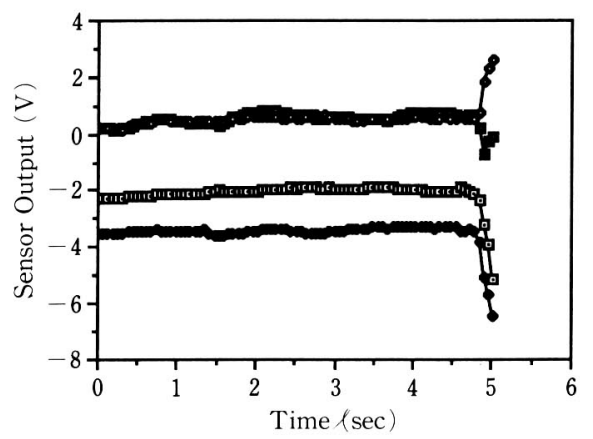

図 10 視線検出データの例（被験者 T. M )

Fig. 10 An example of eye movement detected by sensor (Sub. T. M).

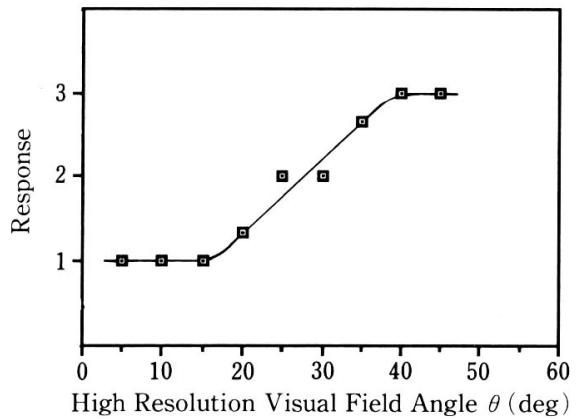

図 9 b 実験結果の例（上昇系列）

Fig. 9b An example of experimental results (ascending series).

こうして計算される高解像度視野角 $\theta_{\mathrm{m}}$ を表 1 の各 組に対してそれぞれ求めた. 表 2 は条件No. 4 および 11 における実験結果（3回の試行の平均值）である. 前述のように両実験では分解能条件はほぼ等しいが, 眼球-ディスプレイ間距離はそれぞれ $20 \mathrm{~cm}$ (No. 4 ), $60 \mathrm{~cm}$ (No. 11) と異なる. 表 2 は異なる観測距 離をもつ等しい周波数条件下の実験がほぼ同一の結果 を与えることを示している.この結果から, 眼球-ディ スプレイ間距離を $60 \mathrm{~cm}, 20 \mathrm{~cm}$ というように変化し ても, 実験によって求められる高解像度視野角 $\theta_{\mathrm{m}}$ デ 一夕はほぼ等しく, 分解能条件の一致する実験結果は ほぼ同等に取り扱えることが判明する。

さて次に, 表 1 の条件 No. 1〜10 について, 中心部 の分解能を $\mathrm{f}_{\mathrm{c}}$, 周辺部のそれを $\mathrm{f}_{\mathrm{p}}$ として $\mathrm{f}_{\mathrm{c}}$ をパラメー 夕に, $\mathrm{f}_{\mathrm{c}} / \mathrm{f}_{\mathrm{p}}$ に対する高解像度視野角 $\theta_{\mathrm{m}}$ の変化をプロ ットすると図 11 のようになる.この図から中心部の分 解能 $\mathrm{f}_{\mathrm{c}}$ を一定とすると, 横軸 $\mathrm{f}_{\mathrm{c}} / \mathrm{f}_{\mathrm{p}}$ の増加に伴い高解 像度視野角 $\theta_{\mathrm{m}}$ は増加し, 約 33 度で飽和することがわ かる.すなわち, この結果から高解像度視野角 $\theta_{\mathrm{m}}$ は $\mathrm{f}_{\mathrm{c}} / \mathrm{f}_{\mathrm{p}}$ の比に依存して決まることがわかる。

図 11 は実験で調整したパラメータ範囲内での結果 を示しているが，より広い範囲で変化する $\mathrm{f}_{\mathrm{c}}, \mathrm{f}_{\mathrm{p}}$ に対 する高解像度視野角 $\theta_{\mathrm{m}}$ の変動傾向を予想するために

表 2 実験結果 (分解能条件 No. 4 おょよび 11)

Tab. 2 Experimental results (The resolution conditions No. 4 and No. 11).

\begin{tabular}{c|c|c|c}
\hline \multirow{2}{*}{ No. } & \multicolumn{3}{|c}{ 高解像度視野角 $\theta_{\mathrm{m}}$} \\
\cline { 2 - 4 } & 被験者 Y. N & 被験者 E. M & 被験者 K. I \\
\hline 4 & 15.0 & 11.5 & 13.3 \\
\hline 11 & 16.5 & 16.0 & 14.1 \\
\hline
\end{tabular}




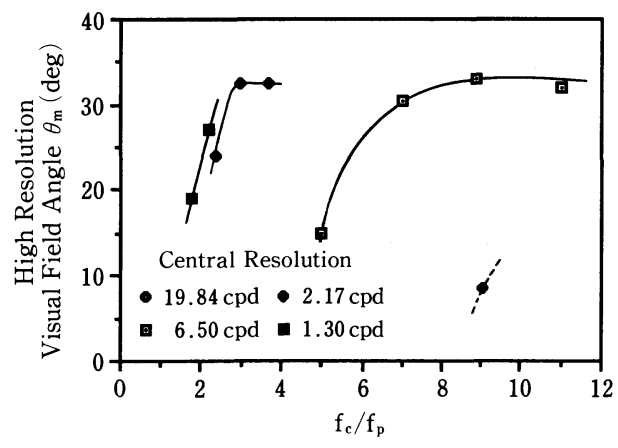

図 $11 \mathrm{f}_{\mathrm{c}} / \mathrm{f}_{\mathrm{p}}$ と高解像度視野角 $\theta_{\mathrm{m}}$ の関係 (被験者 $\mathrm{Y}$. N, 視力 1.2)

Fig. 11 The relation between $f_{c} / f_{p}$ and high resolution visual field angle $\theta_{\mathrm{m}}$ (sub. Y. $\mathrm{N}$, eyesight 1.2).

分解能に変数変換処理を行うことを考える. 一般に 我々はある分解能で表示された模様を見たとき，ある 生理的・心理的過程を経て, 模様がはっきりしている とか，ぼやけているといった認識をもつと考えられる. この認識は, たとえばある分解能の模様に応じて人が もつ感覚量 Sによってなされると仮定する。こうした 感覚量 S は当然, 模様の分解能 $\mathrm{f} の$ 関数になる。ぼけ や明瞭さがある程度以上になると, 人はその差を認識 できなくなるから, 具体的 S の形は $\mathrm{f}$ の両極限 $0, \infty$ に おいて飽和する傾向を示す関数になると考えられる.

そこで分解能 $\mathrm{f}$ の 0 〜の変化に対応して感覚量 $\mathrm{S}$ がそれぞれ 0 あるいは 1 で飽和する変換式に注目する. すなわち, 完全にぼけのない模様に対してもつ感覚量 を $\mathrm{S}=1$, 逆に $\mathrm{f}$ が小さくその模様が知覚できなくな ったときにもつ感覚量を $\mathrm{S}=0$ とし, 分解能 $\mathrm{f}$ が 0 の

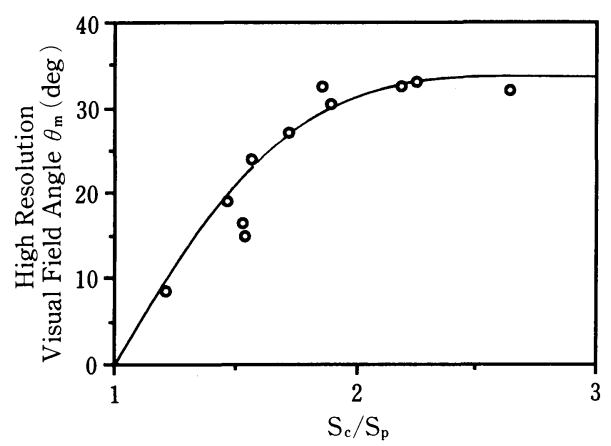

図 $12 \mathrm{a} \quad \mathrm{S}_{\mathrm{c}} / \mathrm{S}_{\mathrm{p}}$ と高解像度視野角 $\theta_{\mathrm{m}}$ の関係 (被 験者 Y. N, 視力 1.2)

Fig. 12 a The relation between $S_{c} / S_{p}$ and high resolution visual field angle $\theta_{\mathrm{m}}$ (sub. Y. N, eyesight 1.2).
とき $\mathrm{S}=0, \mathrm{f}$ が増加するに従い $\mathrm{S}=1$ に飽和する特性 をもつ $\mathrm{f}$ の関数 $\mathrm{S}=\mathrm{S}(\mathrm{f})$ を考える.このような関数は いろいろ考えられるが,ここでは

$$
\begin{gathered}
\mathrm{S}=1-\exp (-\alpha \times \mathrm{f}) \\
\text { (ただし } \alpha: \text { 定数 })
\end{gathered}
$$

とおいてみる。表 1 の各組の条件に対する実験結果に ついて仮に $\alpha=0.8$ として中心部の分解能 $\mathrm{f}=\mathrm{f}_{\mathrm{c}}$ に対 応する感覚量を $S_{c}$, 周辺部 $f=f_{p}$ に対応するそれを $S_{p}$ とし, その比 $\mathrm{S}_{\mathrm{c}} / \mathrm{S}_{\mathrm{p}}$ を横軸, 高解像度視野角 $\theta_{\mathrm{m}}$ を縦軸 に結果を整理すると, 図 12 のようになる.図 $12 \mathrm{a} \sim \mathrm{d}$ はそれぞれの被験者の結果に対応しているが，いずれ の結果もほぼ1つの曲線に乗る傾向を示している， $\alpha$ の值については, 本来なら最適値を求めるべきである が，本実験の目的が高解像度視野角 $\theta_{\mathrm{m}}$ の特性の傾向 を知ることであるので, ここでは $\theta_{\mathrm{m}}$ の特性を知るこ とのできる $\alpha$ を適当に選択するにとどめた.

さて，これらの結果から， $\mathrm{S}_{\mathrm{c}} / \mathrm{S}_{\mathrm{p}}$ を小さくすれば，す なわち縞模様の中心部と周辺部の分解能の差を小さく すれば, 高解像度視野角 $\theta_{\mathrm{m}}$ は小さくなり, $\mathrm{S}_{\mathrm{c}} / \mathrm{S}_{\mathrm{p}}$ を大 きくすれば，すなわち分解能の差を大きくすれば，高 解像度視野角 $\theta_{\mathrm{m}}$ は大きくなることがわかる. 分解能 の差が 0 の状態では高解像度視野角 $\theta_{\mathrm{m}}$ は 0 であるか ら, 分解能の差を小さくしていくと高解像度視野角 $\theta_{\mathrm{m}}$ が 0 に近づくことは容易に予想できる。しかし逆に， 分解能の差を大きくしていくと高解像度視野角 $\theta_{\mathrm{m}}$ は いくらでも大きくなるかといえば必ずしもそうではな く，すでに述べたように，ある一定值で飽和する傾向 が認められる.たとえば図 $12 \mathrm{a}$ の被験者では, ほぼ 33 度で $\theta_{\mathrm{m}}$ は飽和する傾向が認められる.また他の被験 者についても, 図 $12 \mathrm{~b} \sim \mathrm{d}$ から同様の傾向が認められ, 飽和する $\theta_{\mathrm{m}}$ は三者とも約 26 度である。

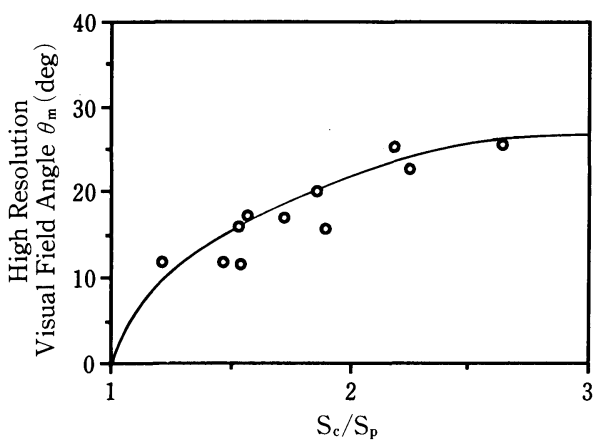

図 $12 \mathrm{~b} \quad \mathrm{~S}_{\mathrm{c}} / \mathrm{S}_{\mathrm{p}}$ と高解像度視野角 $\theta_{\mathrm{m}}$ の関係（被 験者 E. M, 視力 1.0 )

Fig. 12 b The relation between $S_{c} / S_{p}$ and high resolution visual field angle $\theta_{\mathrm{m}}$ (sub. E. M, eyesight 1.0). 
この飽和現象は人の網膜の構造からくるものと考え られる．人の網膜の視細胞である錐体の分布密度は, 視野角に換算して中心窩から \pm 15 度以内で最も高く ${ }^{6}$, その外側では密度が低下し, 高分解能の像を識別する 能力がない. この角度には個人差があるものの, 上述 の視野角 $\theta_{\mathrm{m}}$ が飽和するときの角度にほぼ一致してい る.このことは, 分解能の差にかかわらず中心䈪周辺 の視力の高い領域の外側に境界が結像する場合は, そ の識別が困難になることを示唆しており，この飽和角 度が視線追従型提示系の高解像度ディスプレイの大き さの最大值を決定する際の重要なファクタになると考 えられる。

さて, 以上の実験結果をもとに, 手軽に現状で入手 できる最も解像度の高いディスプレイとしてNTSC 方式 (走查線数 525 本) を想定し, 視線追従型提示系 の高解像度, 低解像度ディスプレイの視野角について 考察する。

まず，各視野角は図 12 より以下の手順で求められ る. 今, NTSC 方式ディスプレイの走査線数を $\mathrm{N}$ 本, 人の視力を損なわない映像提示を可能にするディスプ レイ分解能を $\mathrm{f}_{\mathrm{x}} \mathrm{cpd}$ とすると, 最大高解像度視野角 $\theta_{\mathrm{mx}}$ は定義より次式となる。

$$
\theta_{\mathrm{mx}}=0.5 \mathrm{~N} / \mathrm{f}_{\mathrm{x}}
$$

一方, 図 12 から, この $\theta_{\mathrm{mx}}$ に対応する 2 つの領域の 境界の判別が困難になる中心 ・周辺領域の分解能の比 $\left(\mathrm{S}_{\mathrm{c}} / \mathrm{S}_{\mathrm{p}}\right) \mathrm{x}$ が求まる.この比の $\mathrm{S}_{\mathrm{c}}$ は中心領域の分解能 $\mathrm{f}_{\mathrm{x}}$ より(2)式を計算して求めることができるから, 上記 の比の逆数にこの $\mathrm{S}_{\mathrm{c}}$ を乗じて, 高解像度視野角 $\theta_{\mathrm{mx}}$, 分解能 $\mathrm{f}_{\mathrm{x}} \mathrm{cpd}$ の中心部提示映像との境界が識別でき なくなる周辺部領域の $\mathrm{S}_{\mathrm{p}}$ が決定される。ここで再度 (2)式よりそれに対応する分解能 $\mathrm{f}_{\mathrm{p}} \mathrm{cpd}$ を算出すれば,

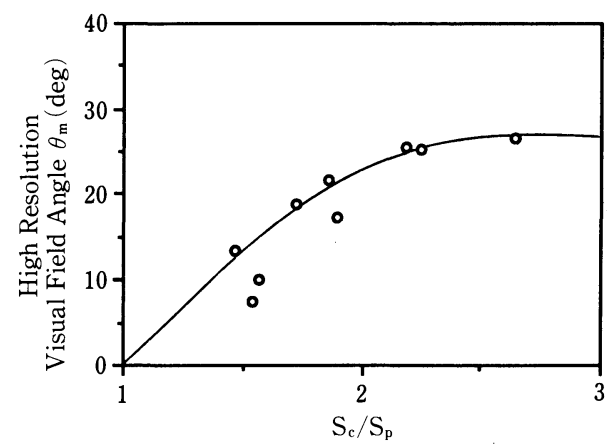

図 12 c $\mathrm{S}_{\mathrm{c}} / \mathrm{S}_{\mathrm{p}}$ と高解像度視野角 $\theta_{\mathrm{m}}$ の関係（被 験者 T. M, 視力 0.8 )

Fig. 12 c The relation between $S_{c} / S_{p}$ and high resolution visual field angle $\theta_{\mathrm{m}}$ (sub. T. M, eyesight 0.8 ).
これょり低解像領域の視野角は, 分解能 $\mathrm{f}_{\mathrm{p}} \mathrm{cpd}$ をもつ 映像をNTSCディスプレイを用いて実現するときの 視野角 $\theta_{\mathrm{x}}$ として, 次式で与えられる.

$$
\theta_{\mathrm{x}}=0.5 \mathrm{~N} / \mathrm{f}_{\mathrm{p}}
$$

以上の計算をより容易に実行することを可能にする ために, $\theta_{\mathrm{mx}}$ と $\theta_{\mathrm{x}}$ の関係を直接表示したグラフを図 13 に示す.なお，この関係は図 $12 \mathrm{a} \sim \mathrm{d}$ のそれぞれについ て作成できるが，ここでは被験者全員が境界の識別が できなくなる $\theta_{\mathrm{mx}}, \theta_{\mathrm{x}}$ を求めるという観点から, 最も大 きな高解像度視野角を示す図 $12 \mathrm{a}$ に注目し作成した。 また，図中の破線は(3)式の関係を併せて表示したもの である.

この図から，たとえば換算視力 $1.0(30 \mathrm{cpd})$ を実現 することを想定する場合，まず破線の関係から高解像 度視野角が約 9 度必要なことがわかる。 また，実線の 関係から，背景の低解像度領域の視野角はおよそ 110 度程度にできることがわかる。言い換えれば，換算視 力 1.0 を実現する EMT-HMD では, NTSC 方式ディ スプレイを用いる場合，高解像度映像の提示用ディス プレイに視野角 9 度, それが提示する像との解像度の 差をわからなくする低解像度映像の提示用ディスプレ イには, 最大で視野角 110 度のものを用いればよいこ とがわかる. 低解像度提示系の視野角 110 度は人の全 視野をほぼカバーしており, EMT-HMD が解像度, 視 野角の両面で十分な仕様をもつ提示系を構築する可能 性を有することが，この結果から判明する。 なお， 110 度の視野角をハイビジョンディスプレイ 1 つで実現す る場合の換算視力は約 $0.3(4.55 \mathrm{cpd})$ であり, NTSC 方式ディスプレイを用いる EMT-HMD は，ハイビジ ヨンを超える分解能をもつ提示系をも提供することが わかる。

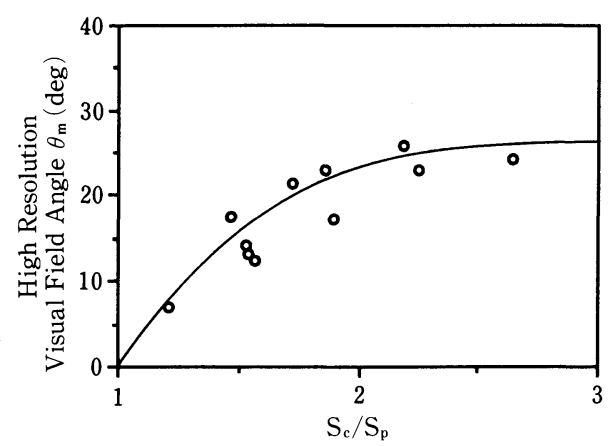

図 $12 \mathrm{~d} \mathrm{~S}_{\mathrm{c}} / \mathrm{S}_{\mathrm{p}}$ と高解像度視野角 $\theta_{\mathrm{m}}$ の関係（被 験者 K. I, 視力 0.3 )

Fig. $12 \mathrm{~d}$ The relation between $\mathrm{S}_{\mathrm{c}} / \mathrm{S}_{\mathrm{p}}$ and high resolution visual field angle $\theta_{\mathrm{m}}$ (sub. K. I, eyesight 0.3). 


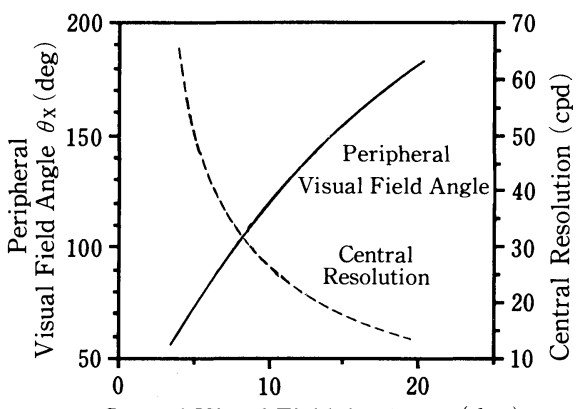

Central Visual Field Angle $\theta_{\mathrm{mx}}(\mathrm{deg})$

図 13 NTSCディスプレイにおける中心部の 視野角と周辺部の視野角および中心部の 分解能の関係

Fig. 13 The relation between central visual field angle and peripheral visual field angle, and central resolution using the NTSC display.

以上のごとく, 図 13 の結果は EMT-HMD のひと つの設計指針を与えるが，実際の HMD の設計にあた っては, 背景の低解像度領域の視野角の技術的制限, 眼球位置の測定誤差, 高解像度映像出力の夕イムラグ などを考慮にいれ，さらに最適化を図る必要があろう。

\section{5. まとめ}

視線追従型 HMD の構造を述べるとともに, 中心部 と周辺部で異なる解像度を有する縦縞模様パターンを 表示刺激に用いて, 解像度の境界を判別させる実験を 行い, 視線追従型映像提示系を設計する際に必要な, 高解像ディスプレイの大きさを決定する基礎デー夕を 明らかにした。結果をまとめると以下のようになる。

（1） 中心部と周辺部で解像度の異なる像を提示した 場合, 解像度の差にかかわらず, 中心部高解像度 像の幅をある值以上にすると，その境界の識別が 困難になる。このときの高解像度視野角は 26〜33 度である.この特性は人の網膜の生理学的構造に 起因すると推定される。

(2) 物理量である空間周波数から感覚量への変換操 作を導入することにより，より広範囲の分解能に 対応した高解像度視野角 $\theta_{\mathrm{m}}$ の変動傾向を推定し た.

（3）上記実験結果より，NTSC 方式のディスプレイ を用いた場合の, 背景の低解像度領域の視野角と それに対応する最適高解像度視野角の関係を考察 した。
本研究では，注視点近傍の視覚特性を静止画像を用 いて検討した。一般に人の視力は, 眼球の高速運動中 に低下寸ることが知られているから，視線が固定され た状態で行われた本研究で得た結論は，異なる分解能 を有する映像の識別の最大能力を与えていると予想さ れ, EMT-HMD の設計基礎データとしては,十分有用 と考えられる.ただし，EMT-HMD の実用下では，当 然ダイナミックな映像の提示が求められるので, より 忠実に視覚特性を評価するためには，動画像を対象と した検討も必要となろう。この点については今後の課 題としたい.

最後に，本研究を進めるにあたり，ご支援いただい た機械技術研究所 大山尚武前ロボット工学部長, およ び実験にご協力いただいたバイオロボティクス課研究 員各位に謝意を表する。

\section{参考文献}

1）前田太郎，荒井裕彦，舘 暲：頭部運動追従型 両眼視覚提示装置の設計と評価, 日本ロボット学 会誌, 10(5)，655〜665，1992.

2）山口博幸, 伴野 明, 岸野文郎：視線検出を利 用する広視野高精細表示方法の検討，電子通信情 報学会論文誌 C-II，J 73-C- II，721～732，1990。

3）岩本和世, 前田太郎, 谷江和雄: 視線追従型へ ッドマウントディスプレイの開発,第 10 回ロボッ 卜学会予縞集, 1081，1992.

4）樋渡涓二：生体情報工学，91～99，コロナ社, 1971.

5) N. M. Dalton, C. S. Deering : Photo Based Image Generator, SPIE, Vol. 1116, HelmetMounted Displays, 61 75, 1989.

6) 渡部 鎣ほか：視覚の科学， 20～25, 写真工業 出版社, 1981 .

7）田崎京二，大山 正，樋渡涓二：視覚情報処理, 371, 朝倉書店, 1984 .

8) V. Virsu, R. Nasanen : Cortical magnification fact or predicts the photopic contrast sensitivity of peripheral vision, Nature, 271, 54 56, 1978.

9）野呂影勇：図解エルゴノミクス, 292, 日本規格 協会，1991.

10）田中良久：心理学的測定法, 34 48, 東京大学 出版会, 1971 .

11) A. Rosenfeld, A. C. Kak : Digital Picture Processing, 158 162, Academic Press, 1976. 


\section{付録：換算視力とハイビジョン映像}

付図 1 に示すように, 人の視力 $V$ は, 知覚できる標 準図形（ランドルト環）の切り欠きの最大幅を見込む 視野角を $\beta$ 分とするとき, 次式によって定義される. $\mathrm{V}=1 / \beta$

この定義を参考にディスプレイに表示される映像が どの程度明瞭に表示されているかを示す尺度として, 換算視力を次のように定義する。すなわち，ディスプ レイの画素の最小幅を $l$ とすれば, 表示しうるランド ルト環の切り欠きの最小幅は $l$ となる. そして,この $l$ は視力のよい人でも知覚できる最小ランドルト環切 り欠き幅となるから，付図 2 に示すように，この $l$ を 見込む角度を $\bar{\beta}$ 分とするとき, 次式の $\overline{\mathrm{V}}$ を換算視力と する。

$$
\overline{\mathrm{V}}=1 / \bar{\beta}
$$

この $\bar{\beta}$ は，ディスプレイの全画面を見込む視野角を $\bar{\beta}_{\mathrm{w}}$, 画面の一次元画素数を $\mathrm{S}_{\mathrm{n}}$ とすれば, 近似的に次式 で計算することもできる.

$$
\bar{\beta}=\bar{\beta}_{\mathrm{w}} / \mathrm{S}_{\mathrm{n}}
$$

一般に我々が用いている TV モニタの方式 (NTSC 方式)では画素の数は $525 \times 525$ である.人の視覚系の 全視野を 80 度とし，これをカバーするNTSC 方式デ イスプレイを用いる場合の換算視力は, 上式から

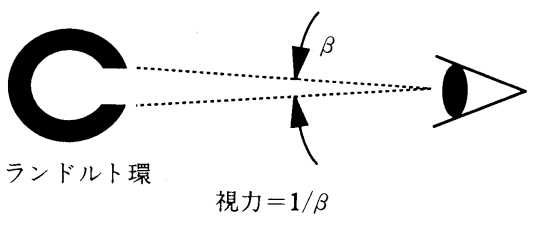

付図 1 視力の計算

Fig. AP 1 Calculation of eyesight.

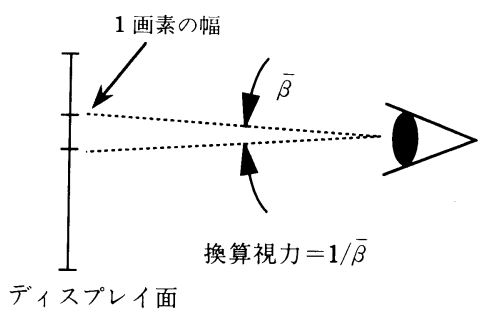

付図 2 換算視力

Fig. AP 2 Equivalent eyesight.

$$
(1 / \bar{\beta})=1 /(80 \times 60 / 525)=0.1
$$

となる.また，たとえ走査線数 2000 本の高品位ディス プレイを用いたとしても，同様に計算される換算視力 は 0.4 であり, 車の運転に必要とされる最低視力 0.7 に及ばない。 